\title{
Using Research Case Studies in eCommerce Marketing Courses: Customer Satisfaction at Point-of-Purchase and Post-Purchase
}

\author{
Noorshella Che Nawi \\ Universiti Malaysia \\ Kelantan, Malaysia
}

norshella\&@umk.edu.my

\section{Michelle Fong and Arthur Tatnall Victoria University, Australia}

michelle.fong@vu.edu.au arthur.tatnall@vu.edu.au

\begin{abstract}
This paper describes a research case study of Internet apparel marketing by small businesses in Malaysia which can beneficially be included in postgraduate business courses for understanding the importance of measuring customer satisfaction at point-of-purchase and post-purchase in online purchases. The sample size in this research is 154 respondents in Malaysia who purchased apparel online and provided their satisfaction level at point-of-purchase and post-purchase stages. Seven-point Likert scale was used to measure the attitude of these respondents in regard to their customer satisfaction. Of the 154 respondents, 64 answered the surveys in Bahasa Melayu (the national language in Malaysia) while the remaining 90 answered in the English language. The case study shows that there are significant differences in all customer satisfaction items between point-of-purchase and post-purchase stages. The results are also different in these items when respondents were differentiated based on the language they used in answering the surveys. Hence, it is important to show students the need to take account of online post-purchase satisfaction as part of the cumulative experience of the online purchaser. Focusing primarily on point-ofpurchase satisfaction could mislead an online retailer particularly if dissatisfaction arose in the aftermath of the purchase experience. In addition, examining customer satisfaction in terms of groups (such as language in this case study) could provide further insight into the significant differences between point-of-purchase and post-purchase in online purchase.
\end{abstract}

Keywords: Case study, customer satisfaction, point-of-purchase, post-purchase, online purchase.

\section{Introduction}

Material published as part of this publication, either on-line or in print, is copyrighted by the Informing Science Institute. Permission to make digital or paper copy of part or all of these works for personal or classroom use is granted without fee provided that the copies are not made or distributed for profit or commercial advantage AND that copies 1) bear this notice in full and 2) give the full citation on the first page. It is permissible to abstract these works so long as credit is given. To copy in all other cases or to republish or to post on a server or to redistribute to lists requires specific permission and payment of a fee. Contact Publisher@InformingScience.org to request redistribution permission.
Many university masters-level business courses contain some component of Information and Communications Technologies (ICT), and often this comes in the form of an Electronic Commerce (eCommerce) elective or even an eCommerce specialisation. Perhaps the most important area for introducing eCommerce concepts is in courses relating to Marketing, as Web Marketing has become extremely important. One of the 
challenges of developing an e-Commerce unit in a postgraduate degree course is to effectively relate the topics covered with those covered in the generic business part of the degree (Tatnall, Groom, \& Burgess 2002). Since the late 1990s the rapidly growth of eCommerce applications on the Web has been apparent to all, and business and management education has taken note of this in their courses, but often such courses are rather theoretical in nature. Successful use of eCommerce requires many changes to business practices and relationships in both business-to-business and business-to-consumer environments and the use of research case studies can facilitate student understanding of this.

This paper describes a research case study of Internet apparel marketing by small businesses in Malaysia which can beneficially be included in postgraduate business courses for understanding the importance of measuring customer satisfaction at point-of-purchase and post-purchase.

\section{Case Study - Customer Satisfaction}

The rapid growth of e-retailing may reflect convincing advantages of shopping through the Internet versus at brick and mortar stores. Consumers may sometimes become frustrated with aspects of e- shopping such as in online purchase of apparel items, and this is important to highlight to students.

Customers take a risk when purchasing apparel online because they cannot try on the garment to check fit, texture, or colour, and this may affect their level of satisfaction (Kim, Kim, \& Lennon, 2006). Customer satisfaction has been extensively studied and constitutes an important concept in the field of marketing (Eshghi, Roy, \& Ganguli, 2008; Helgesen, 2006; Liu, Zeng, Xu, \& Koehl, 2008; Sun \& Kim, 2013). Gaining high levels of customer satisfaction is very important to a business because satisfied customers are most likely to be loyal and to make repeat orders (Anderson \& Fornell, 1994; Anderson \& Srinivasan, 2003; Audrain-Pontevai, Goala \& Poncin, 2013; Freed \& Anderson, 2012; Kuo \& Wu, 2012; Lin, Wu, \& Chang, 2011; Oliver, 1999; Pont \& McQuilken, 2005). In addition, studies have found there is a significant relationship between customer satisfaction and financial performance (Anderson, Fornell \& Rust, 1997; Reichheld \& Sasser, 1990; Rust \& Zahorik, 1993; Sun \& Kim, 2013). Furthermore, understanding consumer satisfaction and behaviour is not only important for companies in ensuring repeat purchase but also for sustaining market share (Garver \& Gagnon, 2002; Kim \& Stoel, 2004; Subramanian, Gunasekaran, Yu, Cheng, \& Ning, 2014; Yuksel \& Yuksel, 2002).

The authors are of the view that it is imperative to consider customer satisfaction at point-of- purchase and post-purchase in an online purchase process in order to better understand consumer purchase behaviour. Customers assess their satisfaction based on their perceived performance (or outcomes) of a product or service in relation to their expectations (Oliver, 1980; Tse \& Wilton, 1988). Customer satisfaction at point-of-purchase refers to customer level of approval towards an object (of evaluation) at the point when the customer makes an online payment for the purchase. Post-purchase, on the other hand, refers to the level of approval at the point when the customer has already received the product and experienced the services that follow the purchase. It is important that customers are satisfied with the online post-purchase service, otherwise the business will lose repeat patronage from customers. Many of the prior service quality measures considered online purchase as a single process, even with after-purchase experience embedded and becoming somewhat obscure in this process (Kim et al. 2006; Muyllea, Moenaert, \& Despontin, 2004; Parasuraman, Zeithaml, \& Malhotra, 2005; Suh \& Han 2003). There have been studies that considered customer satisfaction in post-purchase phase but none in point-of-purchase and postpurchase for a purchase process. This paper attempts to demonstrate the importance of measuring customer satisfaction at both the point-of-purchase and post-purchase in online purchase. 


\section{Literature on Customer Satisfaction}

Studies have shown that higher customer satisfaction can lead to a higher tendency to engage in purchase behaviour (Bai, Law, \& Wen, 2008; Freed \& Anderson, 2012; Lin et al., 2011) and it is important to include this in postgraduate marketing courses. The study undertaken by Bai et al. (2008) found that online satisfaction has a direct and positive effect on purchase intentions. This is supported by another study by Freed and Anderson (2012) who found that highly satisfied online holiday shoppers are $71 \%$ more likely to make an online purchase. Highly satisfied customers are also potential loyal customers who are likely to generate repeat purchases for their suppliers (Anderson \& Fornell, 1994; Anderson \& Srinivasan, 2003; Audrain-Pontevai, et al., 2013; Freed \& Anderson, 2012; Finn, Wang, \& Frank, 2009; Kuo \& Wu, 2012; Lin et al., 2011; Oliver, 1999; Pont \& McQuilken, 2005). Freed and Anderson (2012) found that highly satisfied holiday shoppers are $67 \%$ more likely to make a repeat purchase and $65 \%$ more committed to the brand that generates high level of satisfaction. The reward from nurturing loyal customers lies in the economic returns from repeat purchase behaviour. It has been emphasised by Raphel and Raphel (1995) that the cost of retaining a regular customer is 5 times less than the cost involved in recruiting a new customer. Hence, customer satisfaction could influence the profitability and cost of a company.

Furthermore, highly satisfied customers could be an important source of positive word-of-mouth recommendations and endorsement to friends, family members, or colleagues (Chevalier \& Mayzlin, 2006; Collier, 1995; Duan, Gu, \& Whinston, 2008; Endo, Yang, \& Park, 2012; Finn et al., 2009; Freed \& Anderson, 2012; Jones \& Sasser, 1995; Maxham, 2001; Senecal \& Nantel, 2004). Positive word of mouth from satisfied customers constitutes a powerful input into the decision making process of a potential customer. Freed and Anderson (2012) found that highly satisfied shoppers are $69 \%$ more likely to provide positive influence through word-of-mouth as compared to dissatisfied shoppers. Kuo, Hu, and Yang (2013) highlighted that customers tend to value word-of-mouth from other consumers as more trustworthy and reliable information than promotion information from advertisers or marketers.

While customer satisfaction is not a new concept, few studies focused on the level of customer satisfaction at post-purchase stage. Keeping track of customer satisfaction at post-purchase stage is important because the level of satisfaction may fall to a lower level than at pre-purchase or point-of-purchase stage. If this drop in satisfaction is unchecked, it may result in loss of repeat purchase and future purchase as a result of dissatisfied customers and bad word-of-mouth. It has been highlighted that the awareness of dissatisfied customers at the post-purchase stage allows firms to adopt timely recovery strategies to avert detrimental consequences to the future prospect of the company and, perhaps, also adopt appropriate strategies that may effectively increase customer retention rate and nurture loyal customers (Fagerstrøm \& Ghinea, 2011; Goodwin \& Ross, 1992; Hart, Heskett, \& Sasser, 1990; Kelley, Hoffman, \& Davis, 1993; Kuo \& Wu, 2012). Therefore, it is important for firms not to neglect post-purchase evaluation by online customers, particularly their level of post-purchase satisfaction, when using customer satisfaction as a predictor of future sales (Bai et al., 2008; Endo et al., 2012). Post-purchase satisfaction may make a difference in the marketing strategy employed to enhance economic returns or profitability. For example, Cao and Gruca (2004) found that online retailers were able to charge a premium price in situations where there was high post-purchase satisfaction. Homburg, Koschate, and Hoyer (2005) also found that companies could potentially charge a premium price in situations where customers' cumulative satisfaction is high.

This paper shows that it is important to show students the need to take into account online postpurchase satisfaction as part of the cumulative experience of the online purchaser. Focusing primarily on point-of-purchase satisfaction could mislead an online retailer particularly if dissatisfaction arose in the aftermath of the purchase experience. This paper also investigates the cus- 
tomer satisfaction between point-of-purchase and post-purchase based on language group. According to Haque and Khatibi (2006), language has an impact on online shopping in Malaysia where Malaysian people mostly prefer to surf websites written in Bahasa Melayu. The same argument was shared by Chai, Zadrozny, and Ye (2001) who stated that people less experienced with e-commerce preferred to browse an e-commerce website which used their natural language dialog.

\section{Methodology}

The question that this research sought to address was whether there were differences in customer satisfaction between the pre and post-purchase phases of online shopping. This question is further expanded in the hypotheses below. The sample size in this research is 154 respondents in Malaysia who purchased apparel online and provided their satisfaction level at point-of-purchase and post-purchase stages. The attitudinal statements used to obtain their responses in surveys conducted at both these stages are as follows:

Table 1: Attitudinal statements on customer satisfaction at point-of-purchase and post-purchase

\begin{tabular}{|c|c|c|c|c|c|c|c|}
\hline \multirow{2}{*}{$\begin{array}{l}\text { Attitudinal statements on } \\
\text { customer satisfaction (point- } \\
\text { of-purchase and post- } \\
\text { purchase stages) }\end{array}$} & \multicolumn{7}{|c|}{ 7-point Likert scale: } \\
\hline & $\begin{array}{l}\text { Strongly } \\
\text { Disagree }\end{array}$ & Disagree & $\begin{array}{l}\text { Slightly } \\
\text { Disagree }\end{array}$ & Neutral & $\begin{array}{l}\text { Slightly } \\
\text { Agree }\end{array}$ & Agree & $\begin{array}{l}\text { Strongly } \\
\text { Agree }\end{array}$ \\
\hline $\begin{array}{l}\text { Item 1: I enjoyed purchasing } \\
\text { using the website. }\end{array}$ & & & & & & & \\
\hline $\begin{array}{l}\text { Item 2: Overall, I am satisfied } \\
\text { using the website to purchase } \\
\text { apparel. }\end{array}$ & & & & & & & \\
\hline $\begin{array}{l}\text { Item 3: In general, I was } \\
\text { pleased with the quality of the } \\
\text { service that the website pro- } \\
\text { vided. }\end{array}$ & & & & & & & \\
\hline
\end{tabular}

A seven-point Likert scale was used to measure the attitude of respondents toward each of the above statements. Of the 154 respondents, 64 answered the surveys in Bahasa Melayu (the national language in Malaysia) while the remaining 90 answered in the English language. This study employs Wilcoxon Ranked Sum Test for its non-parametric statistical analyses for investigating whether there are statistically significant differences in customer satisfaction items. The Wilcoxon Ranked Sum test is a distribution-free test because it does not require the assumption that the population is normally distributed. It is designed to match data pairs and used in this study to determine whether there are statistically significant differences in customer satisfaction items between point-of-purchase and post-purchase for all respondents, and within a group (respondents who answered the surveys in English or Bahasa Melayu). The hypothesis statements are as follows:

H1: There is a significant difference in customer satisfaction items between point-of-purchase and post-purchase for all respondents.

H2: There is a significant difference in customer satisfaction items between point-of-purchase and post-purchase for respondents who answered the survey in Bahasa Melayu.

H3: There is a significant difference in customer satisfaction items between point-of-purchase and post-purchase for respondents who answered the survey in English. 


\section{Results and Discussion}

H1: There is a significant difference in customer satisfaction items between point-of-purchase and post-purchase for all respondents.

Tables 2 and 3 show the results for the hypothesis test for H1. H1.1 refers to item 1 attitudinal statement on customer service in $\mathrm{H} 1$ (refer to Table 1), H1.2 refers to item 2 and H1.3 refers to item 3.

Table 2: Results obtained from Wilcoxon Ranked Sum Test on customer satisfaction for all respondents between point-of-purchase and post-purchase.

\begin{tabular}{lllll}
\hline Rank & N & Mean Rank & Sum of Ranks \\
\hline $\begin{array}{l}\text { H1.1. (post-purchase) }- \\
\text { (point-of-purchase) }\end{array}$ & $\begin{array}{l}\text { Negative Ranks } \\
\text { Positive Ranks } \\
\text { Ties }\end{array}$ & $76^{\mathrm{a}}$ & 61.80 & 4696.50 \\
& $39^{\mathrm{b}}$ & 50.60 & 1973.50 \\
& $39^{\mathrm{c}}$ & & \\
$\begin{array}{l}\text { Total } \\
\text { (point-of-purchase) }\end{array}$ & 154 & & \\
& Negative Ranks & $73^{\mathrm{d}}$ & 61.77 & 4509.00 \\
& $\begin{array}{l}\text { Positive Ranks } \\
\text { Ties }\end{array}$ & $40^{\mathrm{e}}$ & 48.30 & 1932.00 \\
& $41^{\mathrm{f}}$ & & \\
$\begin{array}{l}\text { Total } \\
\text { (point-of-purchase) }\end{array}$ & 154 & & 4627.00 \\
& $\begin{array}{l}\text { Negative Ranks } \\
\text { Positive Ranks }\end{array}$ & $76^{\mathrm{g}}$ & 60.88 & 2159.00 \\
& $\begin{array}{l}\text { Ties } \\
\text { Total }\end{array}$ & $38^{\mathrm{i}}$ & 53.98 & \\
\hline
\end{tabular}

a. H1.1 (post-purchase) $<$ (point-of-purchase)

b. H1.1 (post-purchase) $>$ (point-of-purchase)

c. H1.1 (post-purchase $)=($ point-of-purchase $)$

d. H1.2 (post-purchase) $<$ (point-of-purchase)

e. H1.2 (post-purchase) $>$ (point-of-purchase)

f. H1.2 (post-purchase $)=($ point-of-purchase $)$

g. H1.3 (post-purchase) $<$ (point-of-purchase)

h. H1.3 (post-purchase) $>$ (point-of-purchase)

i. H1.3 (post-purchase $)=($ point-of-purchase $)$

Table 3: Test statistics for customer satisfaction (two-tailed test) between point-of-purchase and post-purchase for all respondents Test Statistics ${ }^{\mathrm{a}}$

\begin{tabular}{llll}
\hline & $\begin{array}{l}\text { H1.1. (post-purchase)- } \\
\text { (point-of-purchase) }\end{array}$ & $\begin{array}{l}\text { H1.2. (post-purchase)- } \\
\text { (point-of-purchase) }\end{array}$ & $\begin{array}{l}\text { H1.3. (post-purchase)- } \\
\text { (point-of-purchase) }\end{array}$ \\
\hline Z & $-3.880^{\mathrm{b}}$ & $-3.783^{\mathrm{b}}$ & $-3.474^{\mathrm{b}}$ \\
Asymp. Sig. (2-tailed) & .000 & .000 & .001 \\
\hline
\end{tabular}

a. Wilcoxon Signed Ranks Test

b. Based on positive ranks.

Wilcoxon Signed Ranks Test results in Table 3 show there are statistically significant differences in customer satisfaction items between point-of-purchase and post-purchase at $1 \%$ level of sig- 
nificance. Table 2 also reveals that customers were less satisfied at post-purchase for all these items as compared to point-of-purchase, which is indicated by the higher number of negative ranks as compared to positive ranks and rank ties.

H2: There is a significant difference in customer satisfaction items between point-of-purchase and post-purchase for respondents who answered the survey in Bahasa Melayu.

Tables 4 and 5 show the results for the hypothesis test for $\mathrm{H} 2$. $\mathrm{H} 2.1$ refers to item 1 attitudinal statement on customer service in $\mathrm{H} 2$ (refer to Table 1), $\mathrm{H} 2.2$ refers to item 2 and $\mathrm{H} 2.3$ refers to item 3 .

Table 4: Results obtained from Wilcoxon Ranked Sum Test on customer satisfaction for Bahasa Melayu respondents between point-of-purchase and post-purchase.

\begin{tabular}{|c|c|c|c|c|}
\hline Ranks & & $\mathrm{N}$ & Mean Rank & Sum of Ranks \\
\hline H2.1(post-purchase) -(point- & Negative Ranks & $37^{\mathrm{a}}$ & 24.76 & 916.00 \\
\hline of-purchase) & Positive Ranks & $10^{\mathrm{b}}$ & 21.20 & 212.00 \\
\hline & Ties & $17^{\mathrm{c}}$ & & \\
\hline & Total & 64 & & \\
\hline H2.2(post-purchase) -(point- & Negative Ranks & $34^{\mathrm{d}}$ & 22.68 & 771.00 \\
\hline of-purchase) & Positive Ranks & $9^{e}$ & 19.44 & 175.00 \\
\hline & Ties & $21^{\mathrm{f}}$ & & \\
\hline & Total & 64 & & \\
\hline & Negative Ranks & $37^{g}$ & 21.99 & 813.50 \\
\hline of-purchase) & Positive Ranks & $7^{\mathrm{h}}$ & 25.21 & 176.50 \\
\hline & Ties & $20^{\mathrm{i}}$ & & \\
\hline & Total & 64 & & \\
\hline
\end{tabular}

a. H2.1(post-purchase) $<$ (point-of-purchase)

b. H2.1 (post-purchase) $>$ (point-of-purchase)

c. H2.1(post-purchase) $=1$ (point-of-purchase)

d. H2.2(post-purchase) $<$ (point-of-purchase)

e. H2.2(post-purchase) $>$ (point-of-purchase)

f. $\mathrm{H} 2.2$ (post-purchase) $=$ (point-of-purchase)

g. H2.3(post-purchase) $<$ (point-of-purchase)

h. H2.3(post-purchase) $>$ (point-of-purchase)

i. $\mathrm{H} 2.3$ (post-purchase $)=($ point-of-purchase $)$

Table 5: Test statistics for Bahasa Melayu respondents in customer satisfaction (two-tailed test) between point-of-purchase and post-purchase.

Test Statistics ${ }^{\mathrm{a}}$

\begin{tabular}{llll}
\hline & $\begin{array}{l}\text { H2.1(post-purchase)- } \\
\text { (point-of-purchase) }\end{array}$ & $\begin{array}{l}\text { H2.2(post-purchase)- } \\
\text { (point-of-purchase) }\end{array}$ & $\begin{array}{l}\text { H2.3(post-purchase)- } \\
\text { (point-of-purchase) }\end{array}$ \\
\hline$Z$ & $-3.798^{\mathrm{b}}$ & $-3.671^{\mathrm{b}}$ & $-3.795^{\mathrm{b}}$ \\
Asymp. Sig. (2-tailed) & .000 & .000 & .000 \\
\hline
\end{tabular}

a. Wilcoxon Signed Ranks Test

b. Based on negative ranks. 
Wilcoxon Signed Ranks Test results in Table 5 show there are statistically significant differences in customer satisfaction items between point-of-purchase and post-purchase for respondents who answered the surveys in Bahasa Melayu at significance level of 1\%. Table 4 also reveals that customers were less satisfied at post-purchase for all these items as compared to point-of-purchase, which is indicated by the higher number of negative ranks as compared to positive ranks and rank ties.

H3: There is a significant difference in customer satisfaction items between point-of-purchase and post-purchase for respondents who answered the survey in English.

Tables 6 and 7 show the results for the hypothesis test for H3. H3.1 refers to item 1 attitudinal statement on customer service in H3 (refer to Table 1), H3.2 refers to item 2 and H3.3 refers to item 3.

Table 6: Results obtained from Wilcoxon Ranked Sum Test on Customer Satisfaction for English respondents between point-of-purchase and post-purchase.

\begin{tabular}{lllll} 
Ranks & & $\mathrm{N}$ & Mean Rank & Sum of Ranks \\
\hline H3.1(post-purchase) - & Negative Ranks & $39^{\mathrm{a}}$ & 37.46 & 1461.00 \\
(point-of-purchase) & $\begin{array}{l}\text { Positive Ranks } \\
\text { Ties }\end{array}$ & $29^{\mathrm{b}}$ & 30.52 & 885.00 \\
& $22^{\mathrm{c}}$ & & \\
& Total & 90 & & \\
H.3.2(post-purchase) - & Negative Ranks & $39^{\mathrm{d}}$ & 39.33 & 1534.00 \\
(point-of-purchase) & $\begin{array}{l}\text { Positive Ranks } \\
\text { Ties }\end{array}$ & $31^{\mathrm{e}}$ & 30.68 & 951.00 \\
& $20^{\mathrm{f}}$ & & \\
& Total & 90 & & 1565.00 \\
H.3.3(post-purchase) - & Negative Ranks & $39^{\mathrm{g}}$ & 40.13 & 1063.00 \\
(point-of-purchase) & Positive Ranks & $33^{\mathrm{h}}$ & 32.21 & \\
& Ties & $18^{\mathrm{i}}$ & & \\
& Total & 90 & & \\
\hline
\end{tabular}

a. H.3.1(post-purchase) $<$ (point-of-purchase)

b. H.3.1 (post-purchase) $>$ (point-of-purchase)

c. H.3.1 (post-purchase $)=($ point-of-purchase $)$

d. H.3.2(post-purchase) $<$ (point-of-purchase)

e. H.3.2(post-purchase) $>$ (point-of-purchase)

f. H.3.2 (post-purchase $)=($ point-of-purchase $)$

g. H.3.3(post-purchase) $<$ (point-of-purchase)

h. H.3.3 (post-purchase) $>$ (point-of-purchase)

i. H.3.3(post-purchase) $=$ (point-of-purchase)

Table 7: Test statistics for English respondents in Customer Satisfaction (two-tailed test) between point-of-purchase and post-purchase

Test Statistics ${ }^{\mathrm{a}}$

\begin{tabular}{llll}
\hline & $\begin{array}{l}\text { H3.1(post-purchase)- } \\
\text { (point-of-purchase) }\end{array}$ & $\begin{array}{l}\text { H3.2(post-purchase)- } \\
\text { (point-of-purchase) }\end{array}$ & $\begin{array}{l}\text { H3.3(post-purchase)- } \\
\text { (point-of-purchase) }\end{array}$ \\
\hline$Z$ & $-1.799^{\mathrm{b}}$ & $-1.754^{\mathrm{b}}$ & $-1.439^{\mathrm{b}}$ \\
Asymp. Sig. (2-tailed) & .072 & .079 & .150 \\
\hline
\end{tabular}

a. Wilcoxon Signed Ranks Test

b. Based on positive ranks. 
Table 7 shows there is no statistically significant difference in overall satisfaction between pointof-purchase and post-purchase for respondents who answered the surveys in English at significance level of $1 \%$.

\section{Inclusion of this Material in Postgraduate Business Courses}

If included in a postgraduate business course material of this sort, involving a real case rather than just a textbook example can be very useful in making the student experience much more relevant to them and of much more practical value. This is particularly the case for students from countries other than the USA as many textbook examples are US-based and not immediately relevant to non-US students. In this case, students are shown of the need to take into account both pre- and post-purchase issues when examining the online purchase experience and shown a manner in which this can be done. Here, the case of Malaysia, where many customers do not have English as their first language, adds a different perspective to understanding this topic. As most Internet sites make use of English, how does a non-English speaker get on?

It would be quite easy to adapt this approach for use with another example in another country, particularly if some of your students came from this country and were able to obtain local details of the case. As well as providing useful material for discussion in class, this has the added benefit of involving these overseas students in a quite different way.

\section{Conclusion and Future Research Directions}

In summary (as per Tables 2 and 3), there are significant differences in all customer satisfaction items between point-of-purchase and post-purchase stages for all 154 respondents. However, the results are different in those items where respondents were differentiated based on the language they used in answering the surveys. The levels of customer satisfaction (as measured by [H2.1 point-of-purchase - post-purchase]; [H2.2 point-of-purchase -post-purchase]; [H2.3 point-ofpurchase - post-purchase] in Tables 4 and 5) decreased at post-purchase for those 64 respondents who answered the surveys in Bahasa Melayu. On the other hand, there were no significant differences in the levels of customer satisfaction between point-of-purchase and post-purchase for 90 respondents who answered the surveys in English (as per Tables 6 and 7). The findings demonstrate the importance of measuring customer satisfaction at both point-of-purchase and postpurchase, as well as comparing customer satisfaction between groups based on language. Further investigation is needed to investigate the factors or causes of lower levels of satisfaction when responses differ according to the language used. It is important to determine the causes or factors behind this significant drop in overall satisfaction in this group as the Malay race (who tends to speak Bahasa Melayu) constitutes 55\% of the population in Malaysia and represents a huge potential market to owners of apparel BlogSpots and websites.

With the aid of this up-to-date research in a country where the advent of the Internet, of Web technology, and of eCommerce has only recently begun to make a huge difference, postgraduate students can be introduced to a real case, different to most textbook cases based in countries like the USA. The use of a case from a country like Malaysia adds a different perspective to their understanding of this important topic. 


\section{References}

Anderson, E. W., \& Fornell, C. (1994). A customer satisfaction research prospectus. In R. T. Rust \& R. L. Oliver (Eds.), Service quality: New directions in theory and practice (pp. 241-268). Thousand Oaks, CA: Sage.

Anderson, E. W., Fornell, C., \& Rust, R. T. (1997). Customer satisfaction, productivity and profitability: Differences between goods and services. Marketing Science, 16(2), 129-145.

Anderson, R. E., \& Srinivasan, S. S. (2003). E-satisfaction and e-loyalty: A contingency framework. Psychology and Marketing, 20(2), 123-138.

Audrain-Pontevai, A., Goala, G. N., \& Poncin, I. (2013). A good deal online: The impacts of acquisition and transaction value on e-satisfaction and e-loyalty. Journal of Retailing and Consumer Services, 20(5), 445-452.

Bai, B., Law, R., \& Wen, I. (2008). The impact of website quality customer satisfaction and purchase intentions: Evidence from Chinese online visitors. International Journal of Hospitality Management, 27, 391-402.

Cao, Y., \& Gruca, T. S. (2004). The influence of pre-and post-purchase service on prices in the online book market. Journal of Interactive Marketing, 18(4), 51-62.

Chai, K., Zadrozny, W., \& Ye, Y. (2001). The role of a natural language conversational interface in online sales: A case study. International Journal of Speech Technology, 4(3-4), 285-295.

Chevalier, J., \& Mayzlin, D. (2006). The effect of word of mouth on sales: Online book reviews. Journal of Marketing Research, 43(3), 345-354.

Collier, D. A. (1995). Modeling the relationships between process quality errors and overall service process performance. International Journal of Service Industry Management, 64(4), 4-19.

Duan, W., Gu, B., \& Whinston, A. (2008). The dynamics of online word-of-mouth and product sales: An empirical investigation of the movie industry. Journal of Retailing, 84(2), 233-242.

Endo, S., Yang, J., \& Park, J. (2012). The investigation on dimensions of e-satisfaction for online shoes retailing. Journal of Retailing and Consumer Services, 19(4), 398-405.

Eshghi, A., Roy, S. K., \& Ganguli, S. (2008). Service quality and customer satisfaction: An empirical investigation in Indian mobile telecommunications services. Marketing Management Journal, 18(2), 119-144.

Fagerstrøm, A., \& Ghinea, G. (2011). On the motivating impact of price and online recommendations at the point of online purchase. International Journal of Information Management, 31(2), 103-110.

Finn, A., Wang, L., \& Frank, T. (2009). Attribute perceptions, customer satisfaction and intention to recommend e-services. Journal of Interactive Marketing, 23, 209-220.

Freed, L., \& Anderson, J. (2012). Holiday satisfaction with online shopping stagnates: The foresee e-retail satisfaction index (U.S. Holiday edition 2012). Retrieved on December 8, 2013 from http://www.waafiles.org/whitepapers/online-retail-satisfaction-index-u.s.-holiday-2012-|foresee.pdf

Garver, M. S., \& Gagnon, G. B. (2002). Seven keys to improving customer satisfaction programs. Business Horizons, 45(5), 35-42.

Goodwin, C., \& Ross, I. (1992). Consumer responses to service failures: Influence of procedural and interactional fairness perceptions. Journal of Business Research; 25, 149- 163.

Haque, A., \& Khatibi, A. (2006). The study of the behaviour of Malaysian consumers towards online shopping. Asian Journal of Information Technology, 5(1), 12-19.

Hart, C. W. L., Heskett, J. L., \& Sasser, W. E. (1990). The profitable art of service recovery. Harvard Business Review, 68(4), 148-156. 
Helgesen, Ø. (2006) Are loyal customers profitable? Customer satisfaction, customer (action) loyalty and customer profitability at the individual level. Journal of Marketing Management, 22, 245-266.

Homburg, C., Koschate, N., \& Hoyer, W. D. (2005). Do satisfied customers really pay more? A study of the relationship between customer satisfaction and willingness to pay. Journal of Marketing, 69(2), 8496.

Jones, T.O., \& Sasser, E. S., Jr. (1995). Why satisfied customer defect. Harvard Business Review, 73, 8899.

Kelley, S. W., Hoffman, K. D., \& Davis, M. A. (1993). A typology of retail failures and recoveries. Journal of Retailing, 69(4), 429-52.

Kim, M., Kim, J. H., \& Lennon, S. (2006). Online service attributes available on apparel retail web: An ES-QUAL approach. Managing Service Quality, 16(1), 51-77.

Kim, S., \& Stoel, L. (2004). Apparel retailers: Website quality dimensions and satisfaction. Journal of Retailing and Consumer Services, 11(2), 109-117.

Kuo, Y., \& Wu, C. (2012). Satisfaction and post-purchase intentions with service recovery of online shopping websites: Perspectives on perceived justice and emotions. International Journal of Information Management, 32(2), 127-136.

Kuo, Y., Hu, T., \& Yang, S. (2013). Effects of inertia and satisfaction in female online shoppers on repeatpurchase intention: The moderating roles of word-of-mouth and alternative attraction. Managing Service Quality, 23(3), 168-187.

Lin, C., Wu, H., \& Chang, Y. (2011). The critical factors impact on online customer satisfaction. Procedia Computer Science, 3, 276-281.

Liu, X., Zeng, X., Xu, Y., \& Koehl, L. (2008). A fuzzy model of customer satisfaction index in ecommerce. Mathematics and Computers in Simulation, 77, 512-521.

Maxham, J. G., III (2001). Service recovery's influence on consumer satisfaction, positive word-of-mouth, and purchase intentions. Journal of Business Research, 54(1), 11-24.

Muyllea, S., Moenaert, R., \& Despontin, M. (2004). The conceptualization and empirical validation of web site user satisfaction. Journal of Information and Management, 41, 543-560.

Oliver, R. L. (1980). A cognitive model of the antecedents and consequences of satisfaction decisions. Journal of Marketing Research, 17(4), 460-469.

Oliver, R. L. (1999). Whence consumer loyalty? Journal of Marketing, 63, 33-44.

Parasuraman, A., Zeithaml, V. A., \& Malhotra, A. (2005). E-SQUAL: a multiple-item scale for measuring consumer perceptions for service quality. Journal of Retailing, 7(3), 12-40.

Pont, M., \& McQuilken, L. (2005). An empirical investigation of customer satisfaction and loyalty across two divergent bank segments. Journal of Financial Services Marketing, 9(4), 344-359.

Raphel, N., \& Raphel, M. (1995). Loyalty ladder. Haper Collins Publishers.

Reichheld, F. F., \& Sasser, W. E., Jr. (1990). Zero defections: quality comes. Harvard Business Review, 68(5), 105-111.

Rust, R., \& Zahorik, A. J. (1993). Customer satisfaction, customer retention and market share. Journal of Retailing, 69, 193-215.

Senecal, S., \& Nantel, J. (2004). The influence of online product recommendations on consumers' online choices. Journal of Retailing, 80, 159-169.

Subramanian, N., Gunasekaran, A., Yu, J., Cheng, J., \& Ning, K. (2014). Customer satisfaction and competitiveness in the Chinese E-retailing: Structural equation modelling (SEM) approach to identify the role of quality factors. Expert Systems with Applications, 41, 69-80. 
Suh, B., \& Han, I. (2003). The impact of customer trust and perception of security control on the acceptance of electronic commerce. International Journal of Electronic Commerce, 7(3), 135-161.

Sun, K., \& Kim, D. (2013). Does customer satisfaction increase firm performance? An application of American Customer Satisfaction Index (ACSI). International Journal of Hospitality Management, 35, 68-77.

Tatnall, A., Groom, C., \& Burgess, S. (2002). Electronic commerce specialisations in MBAs: An Australian University case study. Proceedings of the Informing Science and IT Education Conference, Cork, Ireland, University College Cork.

Tse, D. K., \& Wilton, P. C. (1988). Models of consumer satisfaction formation: An extension. Journal of Marketing Research, 25(2), 204-212.

Yuksel, A., \& Yuksel, F. (2002). Measurement of tourist satisfaction with restaurant services: A segmentbased approach. Journal of Vacation Marketing, 9, 52-68.

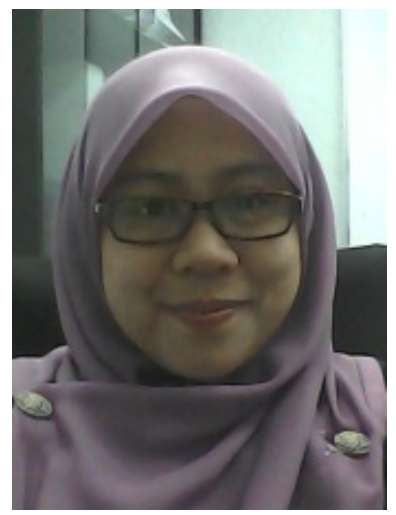

\section{Biographies}

Noorshella Che Nawi is a PhD student in School of Business and Information System at Victoria University. She works as a lecturer at Universiti Malaysia Kelantan, Malaysia. Her research interest includes information technology applications, e-marketing and e-business.

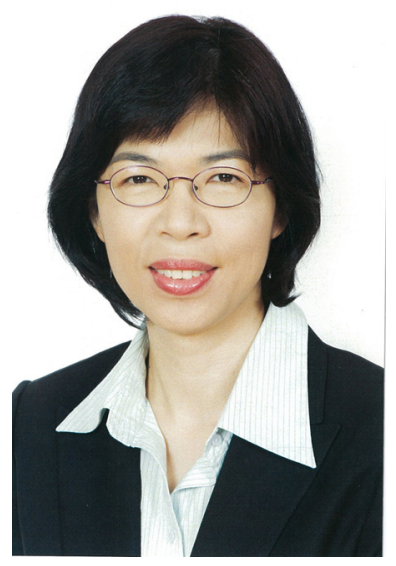

Dr Michelle W. L. Fong is a Senior Lecturer in the College of Business at Victoria University. She has taught in Australia, China, Malaysia, and Singapore. Prior to her academic and research career, she worked with a range of organizational systems in corporations based in different countries. Her research interest includes finance, online education, information technology applications, and e-business.

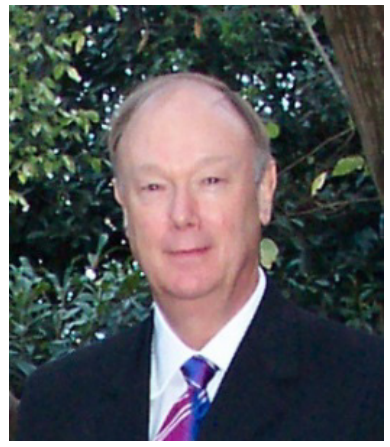

Dr Arthur Tatnall is an Associate Professor in Information Systems at Victoria University, Melbourne, Australia. His research interests include management of technological innovations, history of computing and history of computers in education. He is Chair of IFIP WG3.4 - Professional and Vocational Education in ICT and Editor in Chief of both Education and Information Technologies and the International Journal of Actor-Network Theory and Technological Innovation. 